\title{
Evidence Supporting Transmission of Severe Acute Respiratory Syndrome Coronavirus 2 While Presymptomatic or Asymptomatic
}

\author{
Nathan W. Furukawa, John T. Brooks, Jeremy Sobel
}

\begin{abstract}
Recent epidemiologic, virologic, and modeling reports support the possibility of severe acute respiratory syndrome coronavirus 2 (SARS-CoV-2) transmission from persons who are presymptomatic (SARS-CoV-2 detected before symptom onset) or asymptomatic (SARS-CoV-2 detected but symptoms never develop). SARS-CoV-2 transmission in the absence of symptoms reinforces the value of measures that prevent the spread of SARS-CoV-2 by infected persons who may not exhibit illness despite being infectious. Critical knowledge gaps include the relative incidence of asymptomatic and symptomatic SARS-CoV-2 infection, the public health interventions that prevent asymptomatic transmission, and the question of whether asymptomatic SARS-CoV-2 infection confers protective immunity.
\end{abstract}

\begin{abstract}
s the coronavirus disease (COVID-19) pandem$\mathrm{A}_{\text {ic caused by severe acute respiratory syndrome }}$ coronavirus 2 (SARS-CoV-2) unfolds, an increasing number of reports have indicated that some infected persons may not exhibit signs or symptoms of illness, including persons who are presymptomatic (SARS-CoV-2 RNA is detectable before symptom onset) or asymptomatic (SARS-CoV-2 RNA is detectable but symptoms never develop) (1-8). The detection of SARS-CoV-2 RNA in presymptomatic or asymptomatic persons does not prove that they can transmit the virus to others. We describe evidence that supports the concept of transmission while presymptomatic and asymptomatic, which we found during a rapid literature review conducted at the Centers for Disease Control and Prevention (CDC) in early April 2020.
\end{abstract}

Author affiliation: Centers for Disease Control and Prevention, Atlanta, Georgia, USA

DOI: https://doi.org/10.3201/eid2607.201595

\section{Evidence Supporting Presymptomatic and Asymptomatic Transmission}

We searched the literature in PubMed for articles that were published from January 1 through April 2, 2020, and pertained to presymptomatic or asymptomatic SARS-CoV-2 transmission. This search captured the literature until the time CDC made policy changes recommending community cloth face coverings and universal masking in healthcare facilities. We used combinations of the search terms SARS-CoV-2, COVID-19, asymptomatic, presymptomatic, and transmission. We included original articles, brief reports, and correspondences and excluded reviews, commentaries, opinions, and preprint manuscripts (with the exception of CDC-authored studies that were in review). We classified studies as reporting epidemiologic, virologic, or modeling evidence for presymptomatic or asymptomatic transmission of SARS-CoV-2.

\section{Epidemiologic Evidence}

Most reports of presymptomatic (9-12), asymptomatic (13-15), or a combination of presymptomatic or asymptomatic SARS-CoV-2 transmission $(16,17)$ were from China (Table 1). Presymptomatic or asymptomatic primary patients were typically exposed to SARS-CoV-2 during travel from Wuhan or another city in Hubei Province, China (9-16). One couple was exposed during a mass gathering in Shanghai for the Chinese Spring Festival (17). Reported cases of infected persons who transmitted the virus to others while presymptomatic or asymptomatic have occurred within families or households (9-11,13-17), during shared meals $(10,12)$, or during visits with hospitalized family members $(9,13)$. An inherent confounder to these reports from China is the inability to entirely rule out alternative SARS-CoV-2 exposure in the community early in the 
Table 1. Summary of epidemiologic reports supporting transmission of severe acute respiratory syndrome coronavirus 2 while asymptomatic or presymptomatic*

\begin{tabular}{|c|c|c|c|c|c|c|c|}
\hline Ref. & Setting & $\begin{array}{l}\text { Primary } \\
\text { patient } \\
\text { age, y/sex }\end{array}$ & $\begin{array}{l}\text { Primary patient } \\
\text { exposure }\end{array}$ & Transmission type & $\begin{array}{l}\text { Days from } \\
\text { exposure to } \\
\text { symptoms }\end{array}$ & $\begin{array}{c}\text { Secondary patient } \\
\text { exposure }\end{array}$ & Limitations/strengths \\
\hline (9) & $\begin{array}{l}\text { Xuzhou, } \\
\text { China }\end{array}$ & $56 / \mathrm{M}$ & $\begin{array}{c}\text { Traveled } \\
\text { through Wuhan }\end{array}$ & Presymptomatic & $\geq 5$ & $\begin{array}{c}3 \text { family } \\
\text { household } \\
\text { members, } 3 \\
\text { hospital contacts }\end{array}$ & $\begin{array}{l}\text { L: Possible exposure while } \\
\text { visiting a hospital; unclear } \\
\text { exposure to the primary } \\
\text { patient by the hospital } \\
\text { cluster; possible undetected } \\
\text { community transmission. }\end{array}$ \\
\hline (10) & $\begin{array}{l}\text { Zhoushan, } \\
\text { China }\end{array}$ & $45 / \mathrm{M}$ & Lived in Wuhan & Presymptomatic & $\geq 3$ & $\begin{array}{l}2 \text { work colleagues } \\
\text { sharing dinner }\end{array}$ & $\begin{array}{l}\text { L: Possible exposure from } \\
\text { other conference attendees. }\end{array}$ \\
\hline (11) & $\begin{array}{l}\text { Shanghai, } \\
\text { China }\end{array}$ & $\begin{array}{l}65 / F \\
69 / M\end{array}$ & Lived in Wuhan & Presymptomatic & 6 & $\begin{array}{c}2 \text { family } \\
\text { household } \\
\text { members }\end{array}$ & $\begin{array}{l}\text { L: Possible undetected } \\
\text { community transmission. }\end{array}$ \\
\hline (12) & $\begin{array}{l}\text { Luzhou, } \\
\text { China }\end{array}$ & $\begin{array}{l}50 / \mathrm{M} \\
51 / \mathrm{F} \\
23 / \mathrm{M}\end{array}$ & Lived in Wuhan & Presymptomatic & $\geq 9$ & $\begin{array}{l}2 \text { family members } \\
\text { sharing dinner }\end{array}$ & $\begin{array}{l}\text { L: Possible undetected } \\
\text { community transmission. }\end{array}$ \\
\hline (13) & $\begin{array}{l}\text { Anyang, } \\
\text { China }\end{array}$ & $20 / F$ & $\begin{array}{c}\text { Lived in } \\
\text { Wuhan, China }\end{array}$ & Asymptomatic & NA & $\begin{array}{l}5 \text { family } \\
\text { household } \\
\text { members }\end{array}$ & $\begin{array}{l}\text { L: Initial negative RT-PCR in } \\
\text { the primary case; possible } \\
\text { undetected community } \\
\text { transmission; possible } \\
\text { exposure while visiting a } \\
\text { hospital. }\end{array}$ \\
\hline (14) & $\begin{array}{l}\text { Nanjing, } \\
\text { China }\end{array}$ & $67 / \mathrm{M}$ & $\begin{array}{c}\text { Traveled to } \\
\text { Hubei Province, } \\
\text { China }\end{array}$ & Asymptomatic & NA & $\begin{array}{c}3 \text { family } \\
\text { household } \\
\text { members }\end{array}$ & $\begin{array}{l}\text { L: Possible undetected } \\
\text { community transmission. }\end{array}$ \\
\hline (15) & $\begin{array}{l}\text { Beijing, } \\
\text { China }\end{array}$ & $48 / \mathrm{M}$ & $\begin{array}{l}\text { Traveled to } \\
\text { Wuhan }\end{array}$ & Asymptomatic & NA & $\begin{array}{c}3 \text { family } \\
\text { household } \\
\text { members sharing } \\
\text { a dinner }\end{array}$ & $\begin{array}{l}\text { L: Possible undetected } \\
\text { community transmission. }\end{array}$ \\
\hline (16) & $\begin{array}{l}\text { Guangzhou, } \\
\text { China }\end{array}$ & $35 / \mathrm{M}$ & Lived in Wuhan & $\begin{array}{l}\text { Presymptomatic } \\
\text { or asymptomatic }\end{array}$ & $\geq 4$ & $\begin{array}{l}2 \text { family } \\
\text { household } \\
\text { members }\end{array}$ & $\begin{array}{l}\text { L: Possible infection while } \\
\text { the family was in Wuhan; } \\
\text { primary patient could have } \\
\text { been the wife or son. }\end{array}$ \\
\hline (17) & $\begin{array}{l}\text { Zhejiang, } \\
\text { China }\end{array}$ & $\begin{array}{l}58 / F \\
60 / M\end{array}$ & $\begin{array}{c}\text { Attended } \\
\text { Zhejiang } \\
\text { Chinese Spring } \\
\text { Festival }\end{array}$ & $\begin{array}{l}\text { Presymptomatic } \\
\text { or asymptomatic }\end{array}$ & 5 & $\begin{array}{l}4 \text { family } \\
\text { household } \\
\text { members }\end{array}$ & $\begin{array}{l}\text { L: Unclear nature of the } \\
\text { primary patients' initial } \\
\text { exposure during the visit to a } \\
\text { temple; possible undetected } \\
\text { community transmission. }\end{array}$ \\
\hline (18) & $\begin{array}{l}\text { Munich, } \\
\text { Germany }\end{array}$ & $33 / \mathrm{M}$ & $\begin{array}{c}\text { Visiting } \\
\text { colleague from } \\
\text { China was sick }\end{array}$ & Presymptomatic & 3 & 2 work colleagues & $\begin{array}{l}\text { S: The } 2 \text { secondary cases } \\
\text { had no contact with the sick } \\
\text { colleague from China; no } \\
\text { community spread in } \\
\text { Germany at the time. }\end{array}$ \\
\hline \multirow[t]{7}{*}{ (19) } & Singapore & $\begin{array}{l}55 / \mathrm{F} \\
56 / \mathrm{M}\end{array}$ & $\begin{array}{l}\text { Visited Wuhan } \\
\text { as tourists }\end{array}$ & Presymptomatic & $\geq 4$ & $\begin{array}{l}3 \text { church } \\
\text { attendees }\end{array}$ & \multirow{7}{*}{$\begin{array}{l}\text { S: Limited community } \\
\text { spread in Singapore during } \\
\text { this time. }\end{array}$} \\
\hline & Singapore & $54 / F$ & $\begin{array}{c}\text { Had dinner with } \\
\text { confirmed case- } \\
\text { patient }\end{array}$ & Presymptomatic & 11 & $\begin{array}{l}1 \text { classmate in a } \\
\text { singing class }\end{array}$ & \\
\hline & Singapore & $53 / F$ & $\begin{array}{l}\text { Had contact } \\
\text { with confirmed } \\
\text { case-patient }\end{array}$ & Presymptomatic & 8 & $\begin{array}{l}1 \text { family } \\
\text { household } \\
\text { member }\end{array}$ & \\
\hline & Singapore & $37 / M$ & $\begin{array}{l}\text { Traveled to the } \\
\text { Philippines }\end{array}$ & Presymptomatic & $\geq 6$ & $\begin{array}{l}1 \text { family } \\
\text { household } \\
\text { member }\end{array}$ & \\
\hline & Singapore & $32 / \mathrm{M}$ & $\begin{array}{l}\text { Traveled to } \\
\text { Japan }\end{array}$ & Presymptomatic & $\geq 3$ & $\begin{array}{l}1 \text { household } \\
\text { member }\end{array}$ & \\
\hline & Singapore & $58 / F$ & $\begin{array}{l}\text { Had contact } \\
\text { with confirmed } \\
\text { case-patient }\end{array}$ & Presymptomatic & 5 & $\begin{array}{l}2 \text { church } \\
\text { attendees }\end{array}$ & \\
\hline & Singapore & $63 / \mathrm{M}$ & $\begin{array}{l}\text { Traveled to } \\
\text { Indonesia }\end{array}$ & Presymptomatic & $\geq 2$ & $\begin{array}{c}1 \text { acquaintance } \\
\text { with close contact }\end{array}$ & \\
\hline
\end{tabular}

*L, limitation; NA, not applicable; ref., reference; RT-PCR: reverse-transcription PCR; S, strength. 
outbreak, when transmission in the community may have been undetected.

However, cases of presymptomatic transmission have been reported from other countries before widespread community transmission occurred. A report from Germany documented infection of a German businessman after exposure to a mildly symptomatic colleague visiting from China (18). Before becoming symptomatic, this businessman exposed 2 other colleagues who subsequently received a COVID-19 diagnosis but did not have contact with the primary patient from China or any other known source. A report from Singapore described 7 COVID-19 clusters resulting from presymptomatic transmission; presymptomatic primary patients varied from persons with travel from high-incidence countries to persons exposed in the local community (19). All primary patients experienced distinct periods of initial exposure and presymptomatic close contact with secondary patients who had no other known exposure risks. The incubation periods for presymptomatic primary patients with distinct exposures ranged from 3 to 11 days; for presymptomatic primary patients with travel history to an area with active transmission, the time from last exposure to symptom onset ranged from $\geq 2$ to $\geq 9$ days.

\section{Virologic Evidence}

Currently, SARS-CoV-2 infection is primarily diagnosed by detection of viral RNA via reverse transcription PCR (RT-PCR) or by viral culture and demonstration of cytopathic effect (20). Although RT-PCR identifies viral RNA and cannot determine whether infectious virus is present, infectiousness can be in- ferred from cycle threshold $\left(C_{t}\right)$ values. The RT-PCR $C_{t}$ value represents the number of PCR cycles required to detect SARS-CoV-2 RNA; lower values indicate higher viral load and imply higher infectiousness (20-22). The exact RT-PCR $C_{t}$ values associated with the presence of infectious SARS-CoV-2 is unknown, but infectious virus has been isolated from a specimen with an RT-PCR $C_{t}$ of 34 (23).

Four reports documented the presence of SARSCoV-2 RNA with lower $C_{t}$ values in samples collected from persons in whom symptoms of COVID-19 never developed (24-27) (Table 2). Two reports described specimens with low RT-PCR $C_{t}$ values among presymptomatic and asymptomatic residents of a nursing home identified as part of the same outbreak investigation $(23,28)$. Among these reports, RT-PCR $C_{t}$ values for SARS-CoV-2 RNA in asymptomatically infected persons ranged from 14 to 40 (23-27). The study with data on presymptomatic infected patients reported an average RT-PCR $C_{t}$ value of 24 (range 1538) (23). Two reports described culture of infectious virus from persons with asymptomatic (24) and presymptomatic (23) SARS-CoV-2 infection. Although these reports did not identify actual virus transmission while presymptomatic or asymptomatic, the low RT-PCR $C_{t}$ values (i.e., high viral load) and ability to isolate infectious SARS-CoV-2 provide plausible virologic evidence for SARS-CoV-2 transmission by persons not demonstrating symptoms.

\section{Modeling Evidence}

Two studies used models to estimate the serial interval (time between symptom onset in a primary patient and the secondary patient) $(29,30)$ (Table 3$)$.

\begin{tabular}{|c|c|c|c|c|}
\hline Reference & Setting & Patient(s), age/sex & Laboratory findings & Limitations \\
\hline$(23,28)$ & $\begin{array}{l}\text { Nursing home } \\
\text { outbreak in } \\
\text { Washington }\end{array}$ & $\begin{array}{l}24 \text { presymptomatic } \\
\text { and } 3 \text { asymptomatic }\end{array}$ & $\begin{array}{c}\text { Mean RT-PCR } \mathrm{C}_{\mathrm{t}} \text { value } 24.2 \text { for } \\
\text { presymptomatic and } 27.3 \text { for } \\
\text { asymptomatic patients. Viral culture } \\
\text { identified infectious virus in } 7 \text { (64\%) of } 11 \\
\text { specimens from presymptomatic patients; } \\
\text { no virus detected in } 1 \text { asymptomatic } \\
\text { patient. }\end{array}$ & $\begin{array}{l}\text { Incomplete viral culture } \\
\text { sampling from all } \\
\text { presymptomatic and } \\
\text { asymptomatic patients. }\end{array}$ \\
\hline (24) & $\begin{array}{l}\text { Repatriated to } \\
\text { Germany from } \\
\text { Wuhan, China }\end{array}$ & $\begin{array}{l}2 \text { asymptomatic } \\
\text { adults }\end{array}$ & $\begin{array}{l}\text { Patients' RT-PCR } \mathrm{C}_{\mathrm{t}} \text { values } 24 \text { and } 30 \\
\text { infectious virus was detected by viral } \\
\text { culture for both. }\end{array}$ & $\begin{array}{l}\text { No evidence of transmission } \\
\text { during evacuation flight. }\end{array}$ \\
\hline (25) & $\begin{array}{l}\text { Family cluster in } \\
\text { Singapore }\end{array}$ & $\begin{array}{c}\text { Asymptomatic } 6 \\
\mathrm{mo} / \mathrm{M}\end{array}$ & $\begin{array}{l}\text { RT-PCR } C_{t} \text { values } 14 \text { at diagnosis and } \\
\text { increased to } 33 \text { over } 9 \mathrm{~d} \text {. }\end{array}$ & $\begin{array}{l}\text { No evidence of transmission } \\
\text { from the infant to another } \\
\text { household member. }\end{array}$ \\
\hline$(26)$ & $\begin{array}{l}\text { Cluster in Vietnam } \\
\text { related to travel to } \\
\text { Wuhan }\end{array}$ & $\begin{array}{l}\text { Asymptomatic } 55 \\
\mathrm{y} / \mathrm{M}\end{array}$ & $\begin{array}{l}\text { RT-PCR } C_{t} \text { values }>40 \text { at diagnosis and } \\
\text { during } 9 \mathrm{~d} \text { of viral RNA shedding. }\end{array}$ & $\begin{array}{l}\text { High } \mathrm{C}_{\mathrm{t}} \text { in the asymptomatic } \\
\text { patient suggests minimal } \\
\text { infectiousness. }\end{array}$ \\
\hline$(27)$ & $\begin{array}{l}\text { Family cluster in } \\
\text { Guangdong, China }\end{array}$ & $\begin{array}{l}\text { Asymptomatic, } 26 \\
\text { y/M }\end{array}$ & $\begin{array}{c}\text { RT-PCR } C_{t} \text { values } 22-32 \text { during testing } 7- \\
11 \mathrm{~d} \text { after initial diagnosis. }\end{array}$ & $\begin{array}{l}\text { No evidence of transmission } \\
\text { to other family members in the } \\
\text { cluster. }\end{array}$ \\
\hline
\end{tabular}


Table 3. Summary of modeling reports supporting transmission of severe acute respiratory syndrome coronavirus 2 while asymptomatic and presymptomatic*

\begin{tabular}{|c|c|c|c|}
\hline Reference & Data source & Model findings & Limitations \\
\hline$\overline{(29)}$ & $\begin{array}{l}\text { Confirmed case-patients } \\
\text { from } 18 \text { provincial health } \\
\text { departments in China }\end{array}$ & $\begin{array}{c}\text { The mean serial interval was } 4 \mathrm{~d} \text {, and } \\
\text { symptoms developed in } 13 \% \text { of secondary } \\
\text { case-patients before primary case- } \\
\text { patients, suggesting presymptomatic } \\
\text { transmission. }\end{array}$ & $\begin{array}{l}\text { Data limited to reports of confirmed cases } \\
\text { early in the outbreak; recall bias may } \\
\text { attribute infection to recent exposures and } \\
\text { falsely lower the serial interval. }\end{array}$ \\
\hline$\overline{(30)}$ & $\begin{array}{l}\text { Published articles and case } \\
\text { investigation reports. }\end{array}$ & $\begin{array}{l}\text { The median serial interval was } 4-5 \mathrm{~d} \text {, } \\
\text { depending on the reports analyzed. }\end{array}$ & $\begin{array}{l}\text { Recall bias may attribute infection to } \\
\text { recent exposures and falsely lower the } \\
\text { serial interval. }\end{array}$ \\
\hline$(32)$ & $\begin{array}{l}\text { Spatiotemporal data and } \\
\text { reports on infections of } 375 \\
\text { persons during Spring } \\
\text { Festival, China }\end{array}$ & $\begin{array}{l}\text { An estimated } 86 \% \text { of all infections were } \\
\text { asymptomatic or mild and not reported; up } \\
\text { to } 79 \% \text { of reported cases may have } \\
\text { originated from these unreported } \\
\text { asymptomatic or mild cases. }\end{array}$ & $\begin{array}{c}\text { Data limited to China early in the outbreak; } \\
\text { several assumptions built into a complex } \\
\text { model. }\end{array}$ \\
\hline (33) & $\begin{array}{l}\text { Reports of } 40 \text { manually } \\
\text { selected transmission pairs } \\
\text { from China }\end{array}$ & $\begin{array}{l}\text { On the basis of generation times and } \\
\text { serial intervals, the authors estimated that } \\
\text { one third to one half of transmission } \\
\text { occurred from presymptomatic persons. }\end{array}$ & $\begin{array}{l}\text { Data limited for reports of confirmed cases } \\
\text { early in the outbreak; recall bias may } \\
\text { attribute infection to recent exposures and } \\
\text { falsely lower the serial interval. }\end{array}$ \\
\hline
\end{tabular}

They estimated the serial interval of COVID-19 to be 4 days, which is shorter than the estimated median incubation period for COVID-19 of 5 days (31). One report suggested that up to $13 \%$ of infections may be transmitted during the presymptomatic period of illness (29). These studies relied on reports of primary and secondary cases and may be limited by recall bias; secondary patients are more likely to remember proximal exposures, biasing results toward a shorter serial interval.

Two models attempted to estimate the number of infections caused by asymptomatic, presymptomatic, or mildly symptomatic infected persons $(30,32)$. These models varied widely; 1 model suggested that up to half of infections were transmitted from infected persons who were presymptomatic (33), and another suggested that up to four fifths of infections were transmitted by persons with no symptoms or mild symptoms (32). Both models suggested that a large number of persons with asymptomatic or mildly symptomatic infections were not detected by the health system and that these persons meaningfully contributed to ongoing community transmission $(32,33)$. Although models are highly dependent on the assumptions built into them, these models suggest that the speed and extent of SARS-CoV-2 transmission cannot be accounted for solely by transmission from symptomatic persons.

Each of the epidemiologic, virologic, and modeling studies described has limitations. However, in the aggregate, these diverse studies suggest that SARS-CoV-2 can be transmitted by persons with presymptomatic or asymptomatic infection, which may meaningfully contribute to the propagation of the COVID-19 pandemic. This literature summation was conducted to support changes in CDC recommendations to reduce the risk for asymptomatic transmission and was not a systematic review. These conclusions are drawn from the literature available at the time and may change, given the rapidly evolving nature of the evidence base for asymptomatic transmission.

\section{Public Health Implications of Trans- mission While Asymptomatic}

The existence of persons with asymptomatic SARSCoV-2 infection who are capable of transmitting the virus to others has several implications. First, the case-fatality rate for COVID-19 may be lower than currently estimated ratios if asymptomatic SARSCoV-2 infections are included $(34,35)$. Second, transmission while asymptomatic reinforces the value of community interventions to slow the transmission of COVID-19. Knowing that asymptomatic transmission was a possibility, CDC recommended key interventions including physical distancing (36), use of cloth face coverings in public (37), and universal masking in healthcare facilities (38) to prevent SARS-CoV-2 transmission by asymptomatic and symptomatic persons with SARS-CoV-2 infection. Third, asymptomatic transmission enhances the need to scale up the capacity for widespread testing and thorough contact tracing to detect asymptomatic infections, interrupt undetected transmission chains, and further bend the curve downward.

\section{Science Questions to Inform Public Health Action} The existence of SARS-CoV-2 transmission while infected persons are presymptomatic and asymptomatic raises 3 key questions that need to be answered to inform public health action. First, the incidence of asymptomatic compared with symptomatic SARS- 
CoV-2 infection needs to be determined. The extent of presymptomatic or asymptomatic SARS-CoV-2 infection may be clarified by studies using serial virologic data, serologic data, or a combination of both in observational cohorts or surveillance systems. If a substantial proportion of infections are asymptomatic, enhanced testing strategies may be needed to detect these persons. Second, given that a large proportion of infections probably result from transmission from asymptomatic or presymptomatic persons $(32,33,39)$, the effectiveness of public health interventions aimed at reducing their infectiousness needs to be quantified. If the COVID-19 pandemic is found to be driven by undetected asymptomatic or mildly symptomatic SARS-CoV-2 infections, new innovations in disease detection and prevention (beyond exhaustive contact tracing, mass testing, and isolation of asymptomatic contacts) may be needed. Last, knowledge of SARS-CoV-2 immunity among persons with asymptomatic or mild SARS-CoV-2 infection is needed; specifically, whether full or partial immunity develops in these persons, how long protective immunity lasts, and if it is possible to be immune from reinfection but still asymptomatically transmit SARS-CoV-2 while in a carrier state. This information will be crucial for projecting the anticipated course of the pandemic and the potential for SARS-CoV-2 resurgence if immunity wanes (40). Information about immunity is also valuable for healthcare and other critical infrastructure workers for whom rates of exposure, and thereby asymptomatic infection, may be higher and who therefore warrant data-informed guidance on how to safely return to work. The answers to these questions will be crucial for guiding the gradual relaxing of community interventions, resuming the normal functions of society, and recovering from the COVID-19 pandemic.

\section{About the Author}

Dr. Furukawa is a CDC Epidemic Intelligence Service Officer in the CDC National Center for HIV/AIDS, Viral Hepatitis, STD, and TB Prevention, working on the CDC COVID-19 response clinical team. His research interests include HIV, sexually transmitted diseases, tuberculosis, hepatitis, and Ebola.

\section{References}

1. Wang Y, Liu Y, Liu L, Wang X, Luo N, Ling L. Clinical outcome of 55 asymptomatic cases at the time of hospital admission infected with SARS-coronavirus-2 in Shenzhen, China. J Infect Dis. 2020 Mar 17 [Epub ahead of print]. https://doi.org/10.1093/infdis/jiaa119
2. Chan JF, Yuan S, Kok KH, To KK, Chu H, Yang J, et al. A familial cluster of pneumonia associated with the 2019 novel coronavirus indicating person-to-person transmission: a study of a family cluster. Lancet. 2020;395:514-23. https://doi.org/10.1016/S0140-6736(20)30154-9

3. Chang L, Zhao L, Gong H, Wang L, Wang L. Severe acute respiratory syndrome coronavirus 2 RNA detected in blood donations. Emerg Infect Dis. 2020 Apr 3 [Epub ahead of print]. https:/ / doi.org/10.3201/eid2607.200839

4. Dong Y, Mo X, Hu Y, Qi X, Jiang F, Jiang Z, et al. Epidemiological characteristics of 2143 pediatric patients with 2019 coronavirus disease in China. Pediatrics. 2020; [Epub ahead of print]. https://doi.org/10.1542/ peds.2020-0702

5. Mizumoto K, Kagaya K, Zarebski A, Chowell G. Estimating the asymptomatic proportion of coronavirus disease 2019 (COVID-19) cases on board the Diamond Princess cruise ship, Yokohama, Japan, 2020. Euro Surveill. 2020;25: Epub ahead of print. https://doi.org/10.2807/ 1560-7917.ES.2020.25.10.2000180

6. Roxby AC, Greninger AL, Hatfield KM, Lynch JB, Dellit TH, James A, et al. Detection of SARS-CoV-2 among residents and staff members of an independent and assisted living community for older adults- Seattle, Washington, 2020. MMWR Morb Mortal Wkly Rep. 2020;69:416-8. https://doi.org/10.15585/mmwr.mm6914e2

7. Tian S, Hu N, Lou J, Chen K, Kang X, Xiang Z, et al. Characteristics of COVID-19 infection in Beijing. J Infect. 2020;80:401-6. https:// doi.org/10.1016/j.jinf.2020.02.018

8. Ng O-T, Marimuthu K, Chia P-Y, Koh V, Chiew CJ, De Wang L, et al. SARS-CoV-2 infection among travelers returning from Wuhan, China. N Engl J Med. 2020;382:14768. https:// doi.org/10.1056/NEJMc2003100

9. Li C, Ji F, Wang L, Wang L, Hao J, Dai M, et al. Asymptomatic and human-to-human transmission of SARS-CoV-2 in a 2-family cluster, Xuzhou, China. Emerg Infect Dis. 2020 Mar 31 [Epub ahead of print]. https://doi.org/10.3201/ eid2607.200718

10. Tong ZD, Tang A, Li KF, Li P, Wang HL, Yi JP, et al. Potential presymptomatic transmission of SARS-CoV-2, Zhejiang Province, China, 2020. Emerg Infect Dis. 2020;26:1052-4 https://doi.org/10.3201/eid2605.200198

11. Yu P, Zhu J, Zhang Z, Han Y, Huang L. A familial cluster of infection associated with the 2019 novel coronavirus indicating potential person-to-person transmission during the incubation period. J Infect Dis. 2020 Feb 18 [Epub ahead of print]. https://doi.org/10.1093/infdis/jiaa077

12. Ye F, Xu S, Rong Z, Xu R, Liu X, Deng P, et al. Delivery of infection from asymptomatic carriers of COVID-19 in a familial cluster. Int J Infect Dis. 2020;94:133-8; Epub ahead of print. https:/ / doi.org/10.1016/j.ijid.2020.03.042

13. Bai Y, Yao L, Wei T, Tian F, Jin DY, Chen L, et al. Presumed asymptomatic carrier transmission of COVID-19. JAMA. 2020;323:1406. https://doi.org/10.1001/jama.2020.2565

14. Hu Z, Song C, Xu C, Jin G, Chen Y, Xu X, et al. Clinical characteristics of 24 asymptomatic infections with COVID-19 screened among close contacts in Nanjing, China. Sci China Life Sci. 2020;63:706-11. https://doi.org/10.1007/ s11427-020-1661-4

15. Zhang J, Tian S, Lou J, Chen Y. Familial cluster of COVID-19 infection from an asymptomatic. Crit Care. 2020;24:119. https://doi.org/10.1186/s13054-020-2817-7

16. Pan X, Chen D, Xia Y, Wu X, Li T, Ou X, et al. Asymptomatic cases in a family cluster with SARS-CoV-2 infection. Lancet Infect Dis. 2020;20:410-1. https:// doi.org/10.1016/S14733099(20)30114-6 
17. Qian G, Yang N, Ma AHY, Wang L, Li G, Chen X, et al. A COVID-19 transmission within a family cluster by presymptomatic infectors in China. Clin Infect Dis. 2020 Mar 23 [Epub ahead of print]. https://doi.org/10.1093/cid/ ciaa316

18. Rothe C, Schunk M, Sothmann P, Bretzel G, Froeschl G, Wallrauch C, et al. Transmission of 2019-nCoV infection from an asymptomatic contact in Germany. N Engl J Med. 2020;382:970-1. https://doi.org/10.1056/NEJMc2001468

19. Wei WE, Li Z, Chiew CJ, Yong SE, Toh MP, Lee VJ. Presymptomatic transmission of SARS-CoV-2 - Singapore, January 23-March 16, 2020. MMWR Morb Mortal Wkly Rep. 2020;69:411-5. https://doi.org/10.15585/mmwr.mm6914e1

20. Loeffelholz MJ, Tang YW. Laboratory diagnosis of emerging human coronavirus infections-the state of the art. Emerg Microbes Infect. 2020;9:747-56. https://doi.org/10.1080/222 21751.2020.1745095

21. Corman VM, Landt O, Kaiser M, Molenkamp R, Meijer A, Chu DKW, et al. Detection of 2019 novel coronavirus (2019-nCoV) by real-time RT-PCR. Euro Surveill. 2020;25: Epub ahead of print. https:// doi.org/10.2807/1560-7917. ES.2020.25.3.2000045

22. Wölfel R, Corman VM, Guggemos W, Seilmaier M, Zange S, Müller MA, et al. Virological assessment of hospitalized patients with COVID-2019. Nature. 2020 Apr 1 [Epub ahead of print]. https:/ /doi.org/10.1038/s41586-020-2196-x

23. Arons MM, Hatfield KM, Reddy SC, Kimball A, James A, Jacobs JR, et al. Presymptomatic SARS-CoV-2 infections and transmission in a skilled nursing facility. N Engl J Med. 2020 Apr 24 [Epub ahead of print]. https://doi.org/10.1056/ NEJMoa2008457

24. Hoehl S, Rabenau H, Berger A, Kortenbusch M, Cinatl J, Bojkova D, et al. Evidence of SARS-CoV-2 infection in returning travelers from Wuhan, China. N Engl J Med. 2020;382:1278-80. https://doi.org/10.1056/NEJMc2001899

25. Kam KQ, Yung CF, Cui L, Tzer Pin Lin R, Mak TM, Maiwald $\mathrm{M}$, et al. A well infant with coronavirus disease 2019 with high viral load. Clin Infect Dis. 2020 Feb 28 [Epub ahead of print]. https://doi.org/10.1093/cid/ciaa201

26. Le TQM, Takemura T, Moi ML, Nabeshima T, Nguyen LKH, Hoang VMP, et al. Severe acute respiratory syndrome coronavirus 2 shedding by travelers, Vietnam, 2020. Emerg Infect Dis. 2020 Apr 2 [Epub ahead of print]. https://doi.org/10.3201/eid2607.200591

27. Zou L, Ruan F, Huang M, Liang L, Huang H, Hong Z, et al. SARS-CoV-2 viral load in upper respiratory specimens of infected patients. N Engl J Med. 2020;382:1177-9. https:/ / doi.org/10.1056/NEJMc2001737

28. Kimball A, Hatfield KM, Arons M, James A, Taylor J, Spicer K, et al.; Public Health - Seattle \& King County; CDC COVID-19 Investigation Team. Asymptomatic and presymptomatic SARS-CoV-2 infections in residents of a long-term care skilled nursing facility - King County, Washington, March 2020. MMWR Morb Mortal Wkly Rep. 2020;69:377-81; Epub ahead of print. https://doi.org/ 10.15585/mmwr.mm6913e1
29. Du Z, Xu X, Wu Y, Wang L, Cowling BJ, Meyers LA. Serial interval of COVID-19 among publicly reported confirmed cases. Emerg Infect Dis. 2020 Mar 19 [Epub ahead of print]. https://doi.org/10.3201/eid2606.200357

30. Nishiura H, Linton NM, Akhmetzhanov AR. Serial interval of novel coronavirus (COVID-19) infections. Int J Infect Dis. 2020;93:284-6. https:// doi.org/10.1016/j.ijid.2020.02.060

31. Lauer SA, Grantz KH, Bi Q, Jones FK, Zheng Q, Meredith HR, et al. The incubation period of coronavirus disease 2019 (COVID-19) from publicly reported confirmed cases: estimation and application. Ann Intern Med. 2020 Mar 10 [Epub ahead of print]. https:/ / doi.org/10.7326/M20-0504

32. Li R, Pei S, Chen B, Song Y, Zhang T, Yang W, et al. Substantial undocumented infection facilitates the rapid dissemination of novel coronavirus (SARS-CoV2). Science. 2020;368:489-93; [Epub ahead of print]. https://doi.org/10.1126/science.abb3221

33. Ferretti L, Wymant C, Kendall M, Zhao L, Nurtay A, Abeler-Dörner L, et al. Quantifying SARS-CoV-2 transmission suggests epidemic control with digital contact tracing. Science. 2020;eabb6936; Epub ahead of print. https://doi.org/10.1126/science.abb6936

34. Verity R, Okell LC, Dorigatti I, Winskill P, Whittaker C, Imai $\mathrm{N}$, et al. Estimates of the severity of coronavirus disease 2019: a model-based analysis. Lancet Infect Dis. 2020 Mar 30 [Epub ahead of print]. https://doi.org/10.1016/ S1473-3099(20)30243-7

35. Wu JT, Leung K, Bushman M, Kishore N, Niehus R, de Salazar PM, et al. Estimating clinical severity of COVID-19 from the transmission dynamics in Wuhan, China. Nat Med. 2020;26:506-10. https://doi.org/10.1038/s41591-020-0822-7

36. Lasry A, Kidder D, Hast M, Poovey J, Sunshine G, Winglee $\mathrm{K}$, et al. Timing of community mitigation and changes in reported covid-19 and community mobility - four US metropolitan areas, February 26-April 1, 2020. MMWR Morb Mortal Wkly Rep. 2020 Apr 13 [Epub ahead of print]. http:/ / dx.doi.org/10.15585/mmwr.mm6915e2external icon

37. Mahase E. Covid-19: what is the evidence for cloth masks? BMJ. 2020;369:m1422. https:/ / doi.org/10.1136/bmj.m1422

38. Klompas M, Morris CA, Sinclair J, Pearson M, Shenoy ES. Universal masking in hospitals in the COVID-19 era. N Engl J Med. 2020 Apr 1 [Epub ahead of print]. https:/ / doi.org/10.1056/NEJMp2006372

39. He X, Lau EHY, Wu P, Deng X, Wang J, Hao X, et al. Temporal dynamics in viral shedding and transmissibility of COVID-19. Nat Med. 2020 Apr 15 [Epub ahead of print].

40. Kissler SM, Tedijanto C, Goldstein E, Grad YH, Lipsitch M. Projecting the transmission dynamics of SARS-CoV-2 through the postpandemic period. Science. 2020;eabb5793; Epub ahead of print. https:/ / doi.org/ 10.1126/science.abb5793

Address for correspondence: Nathan W. Furukawa, Centers for Disease Control and Prevention, 1600 Clifton Rd NE, Mailstop US8-4, Atlanta, GA 30329-4027, USA; email: nmt6@cdc.gov 